\title{
WORKPLACE HUMAN IMMUNE VIRUS/ACQUIRED IMMUNO DEFICIENCY SYNDROME (HIV/AIDS) POLICY AND IMPACT ON KNOWLEDGE LEVELS: A STUDY OF PRIVATE COMPANIES IN THE WESTERN REGION
}

\author{
I. Decardi-Nelson ${ }^{1}$ and Y. Nsiah-Peprah ${ }^{2}$ \\ ${ }^{1}$ CSIR - Building and Road Research Institute \\ Email:pkow_mey@yahoo.co.uk \\ ${ }^{2}$ Department of Planning, College of Architecture and Planning \\ Kwame Nkrumah University of Science and Technology, Kumasi \\ ynsiahpeprah@yahoo.com
}

\begin{abstract}
The urgent need for the HIVIAIDS pandemic to be tackled at the workplace cannot be overemphasized given the internal and external impacts it has on businesses. This led to the formulation of the National HIVIAIDS Workplace Policy to be replicated by companies especially the private sector which is the engine of growth. A sample of 155 private companies (five with HIVIAIDS workplace policy and 150 without the policy) in the Western Region was selected for comparative analysis through interviews using the purposive, cluster and simple random sampling techniques. The results indicated that the knowledge levels of managers of private companies on HIVIAIDS issues and their appreciation of the impact of the pandemic would influence the quantum of resources to be committed to reduce the prevalence rate. Thus, the formulation and implementation of HIVIAIDS workplace policies could lead to an increase in the knowledge levels of both workers and managers and it is hoped that in the long run, it would result in a reduction in the prevalence levels.
\end{abstract}

Keywords: Acquired Immune Deficiency Syndrome (AIDS), Human Immunodeficiency Virus (HIV), Private Sector, Knowledge Levels, Companies.

\section{INTRODUCTION}

Globally, HIV/AIDS pandemic has reached crisis proportions as it is now a major developmental and human rights issue (Amoa, 2004). It is said to be among the leading cause of death especially in Sub-Saharan Africa with a prevalence rate of 8.9 percent, compared with the world's rate of 1.7 percent (Ghana AIDS Commission, 2005a). Ghana is one of the few countries regarded as having a low prevalence rate of 3.2 percent even though the prevalence rate has increased from the 2005 figure of 2.6 percent (Ghana AIDS Commission, 2005b). There is therefore the urgent need for all necessary interventions to avert the human and economic consequences.

The impact of the pandemic on businesses and for that matter economic development of a nation cannot be over emphasised. The HIV/ AIDS pandemic has both internal and external impacts on the productive sector of the economy. Some of the major internal impacts include declining productivity, increasing health care bills and increasing labour costs due to increasing staff absenteeism. The external im- 
pacts include reduced potential market and purchasing power of companies. These aside, the human resource of the nation (employees) spend about one third of the day at the workplace. All the above facts have made it very justifiable that the fight against the HIV/AIDS pandemic be taken to the workplace. This resulted in the Government of Ghana formulating a National HIV/AIDS Workplace Policy, which is to provide the framework for Ghana's strategy to reduce the spread and mitigate the impact of the disease on the workforce of the country. This new direction has been well acknowledged, accepted and adopted by most Ministries, Departments and Agencies (MDAs) in Ghana.

However, the contribution of the private sector to the success of any policy more especially the National HIV/AIDS Workplace Policy is very crucial. Since the 1990s, successive governments have identified it as the "pusher" of the economy. Indications are that the private sector has not become engrossed in the implementation of this policy. However, the sector is known to employ close to 60 percent of the labour force (GoG, 2005). This notwithstanding, some private companies (multi-nationals) are implementing the policy and are reaping its benefits. This paper seeks to undertake a comparative analysis of the knowledge levels on HIV/AIDS between private companies with the policy and those without. The goal is to assess the impact of the implementation of the policy on knowledge levels in a bid to reduce the prevalence rate. The specific objectives are: to identify the number of private firms or enterprises that have working HIV/AIDS workplace policies in the Western Region in order to assess the outcomes; and to identify the way forward with regards to the private sector working with the policy. It is also hoped that the benefits enjoyed by the implementing companies would push the none-implementing companies to get involved.

The Global HIV/AIDS Workplace Policy According to the International Labour Organi- zation (2000), HIV/AIDS is a major threat to the 'world of work' because it is affecting the most productive segment of the labour force. It is imposing huge costs on enterprises in all sectors through declining productivity and earnings, increasing labour costs and loss of skilled and experienced labour force. Additionally, it creates unwarranted stigmatization and discrimination aimed at people living with and affected by HIV/AIDS within the workplace.

AIDS-related illnesses and deaths of employees affect private sector firms by increasing expenditures and reducing revenues. Industries relying on a high level of skilled labour and in an environment of high HIV prevalence are most vulnerable. The main effect of HIV-AIDS on industry is through increased labour costs and decreased availability of skilled labour (Decosas and Adrien, 1997).

According to Yeboah-Duah (2002), an HIV/ AIDS Workplace Policy defines an organization's position and practices for preventing the transmission of HIV and for handling cases of HIV infection among employees. Businesses experiences in addressing the HIV/AIDS pandemic suggest that it is useful to have a written policy stating the company's position and procedures to guide managers and employees. HIV/AIDS policies can be many pages long or as short as a few paragraphs. Usually the length of the policy depends on whether it simply outlines broad policy guidelines or provides detailed instructions and procedures on how the policy is to be enacted. It also seeks to: set a foundation for an HIV/AIDS prevention programme; offer a framework for consistency of practice within a business; express the standards of behaviour expected of all employees; let all employees know what assistance is available and where to go for it; instruct supervisors and managers on how to manage HIV/AIDS in their work groups; and ensure consistency with any relevant national statutes (WHO, 2007).

Workplace HIV/AIDS policies range from inhouse prevention to education, service delivery 
and support for community prevention efforts. The most effective workplace prevention policies consist of a comprehensive and coordinated set of components which are written down. Written HIV/AIDS policies provide clarity and certainty about a subject many people find confusing and uncertain. According to Yeboah-Duah (2002), an ideal HIV/AIDS Workplace Policy should contain the following:

- People with HIV/AIDS are entitled to the same rights, benefits and opportunities as people with other serious or lifethreatening illnesses;

- Employment practices related to HIV/ AIDS should comply with national, regional and local laws and regulations;

- Employment policies should be based on the scientific and epidemiological evidence that people with HIV/AIDS do not pose a risk transmitting HIV to co-workers through ordinary workplace contact;

- The highest levels of management, union and other worker leadership endorse nondiscriminatory employment policies and educational programs about HIV/AIDS;

- Employers, unions and other worker representatives should communicate their support of these policies to employees in simple, clear and unambiguous terms;

- Employers should provide employees with sensitive and up-to-date training about HIV/AIDS risk reduction in their personal lives;

- It should state that employers would protect the confidentiality of employees' medical information and prevent work disruption and rejection by co-workers of an employee with HIV/AIDS;

- Employers should not require HIV screening as part of pre-employment or general workplace physical examination; and

- In special occupational settings where workers are regularly exposed to human blood or blood products, such as health care facilities, there may be potential risk of exposure to HIV/AIDS. In such settings, employers should provide ongoing educa- tion and training to reinforce appropriate infection control procedures and ensure that they are implemented.

\section{The Ghanaian HIV/AIDS Workplace Policy}

The HIV/AIDS pandemic poses a serious challenge to the development efforts of most countries including Ghana. This is because it is capable of reversing the modest human capital gains made.

In Ghana, attempts by many studies to isolate the macro economic impact of the HIV/AIDS pandemic have not been very conclusive because the relationship between the pandemic and economic performance is complex (Decosas and Adrien, 1997). However, some studies have been able to provide a more detailed view of the economic consequences of the disease in industry, in geographic regions and on specific demographic groups. One such study by Decosas (1996) indicated an HIV infection of 5 to 10 percent higher in a rural district where a major construction work was taking place than in neighbouring districts. Not only did the construction work draw workers away from their families and increased commercial sex work in the area but it displaced about 80,000 inhabitants.

After all the seemingly disjointed efforts of the Government of Ghana at bringing the fight against the pandemic to where the people make their living (workplace), the government has formulated a comprehensive National Workplace HIV/AIDS Policy to provide essential guidance to employers and workers and to provide care and support for the vulnerable groups. The Policy was formulated because it was and is seen as the best practice for the control and management of the HIV/AIDS pandemic at the workplace.

Due to the commitment of the government and the overseeing role of the Ghana AIDS Commission, a National Workplace HIV/AIDS Policy has been developed. This document was prepared by the National Tripartite Committee 


\section{Decardi-Nelson and Nsiah-Peprah}

(NTC), comprising Organized Labour, Ghana Employers' Association and Government. It provides essential guidance to policy makers, employers and workers' organizations to help them implement workplace policies. The policy also addresses the needs of vulnerable groups and provides care and support for them.

The goal of the Policy is to provide broad national guidelines to direct the formulation of workplace policies and programmes. The specific objectives are to provide protection from discrimination in the workplace to people living with HIV and AIDS; to prevent HIV and AIDS spread amongst workers; and to provide care, support and counseling for those infected and affected (Ghana AIDS Commission, 2005c).

\section{Principles of the Ghanaian Policy}

The major underlining concepts of the Policy are the Behaviour Change Communication (BCC) and Corporate Social Responsibility (CSR). The Policy is guided by the Constitution of Ghana and key principles as developed by the International Labour Organization (ILO) which have been stated earlier in this paper. The principles according to the Ghana AIDS Commission (2005c) apart from those stated in the global policy include:

- The gender dimensions of HIV/AIDS should be recognized because it affects women and men differently in terms of vulnerability and impact and these are important when developing workplace policies;

- The work environment should be healthy and safe;

- As with many other conditions, persons with HIV-related illnesses should be al lowed to work for as long as medically fit; and

- New infections should be prevented be cause HIV infections are preventable through changes in attitude and behaviour which is normally through the provision of information and education.

\section{METHODOLOGY OF STUDY}

Geographically, the study focused on the Western Region of Ghana. The reasons are that it has the second highest prevalence rate of HIV/ AIDS of $4.3 \%$ in the country and it is a border region and also one of the four most deprived regions. The case study method was used for the study. The study went on to do a comparative analysis between private companies that have formulated HIV/AIDS workplace policies and are implementing them and private companies without the workplace policy. This was done through interviews using a combination of probability (the cluster and simple random sampling techniques) and non-probability sampling methods (the purposive sampling technique). Only five companies within the region were identified to have HIV/AIDS workplace policies and all were purposively sampled. Incidentally, they were the multinational mining companies located in the Wassa District such as AngloGold Ghana Iduapriem Limited (AAIL), Goldfields Ghana Limited, Golden Star Resources Limited, Central Ashanti Gold Limited and Dameng Mine.

The probability sampling methods were used for sampling the companies without HIV/AIDS policies based on the 2003 Industrial Census. Here, the companies in the region were clustered into districts and the companies within each district were randomly selected. The 2003 Industrial Census reported a total of about 1192 privately owned small and large scale companies in the Western Region, which is $49 \%$ of the national figure. A sample of 150 companies constituting $12.6 \%$ of the total number of private companies within the region was selected excluding the five companies with workplace HIV/AIDS policies. The ratio and proportion method was applied in calculating the sample size for each district/cluster. Majority of the sampled companies were into service provision while the agro-processing companies were in the minority. Most companies did not wish their names to be used for the study and hence the list of companies cannot be provided. However, Table 1 indicates the sample size per dis- 
Workplace HIV/AIDS Policy and impact on Knowledge levels...

trict/cluster.

Table 1: Sampled private companies by district

\begin{tabular}{lll}
\hline District & $\begin{array}{l}\text { No. of Private } \\
\text { Companies }\end{array}$ & $\begin{array}{l}\text { Sample } \\
\text { Size }\end{array}$ \\
\hline Jomoro & 69 & 9 \\
Nzema East & 88 & 11 \\
Ahanta West & 59 & 7 \\
Shama-Ahanta East & 229 & 29 \\
Mpohor Wassa & 76 & 10 \\
East & & \\
Wassa West & 144 & 18 \\
Wassa Amenfi & 145 & 18 \\
Aowin-Suaman & 74 & 9 \\
Juabeso-Bia & 151 & 19 \\
Sefwi-Wiawso & 92 & 12 \\
Bibiani-Anhwiaso- & 65 & 8 \\
Bekwai & & $\mathbf{1 5 0}$ \\
Total & $\mathbf{1 1 9 1}$ & Census
\end{tabular}

Source: Extracted from the Industrial Census, 2003.

In each company, a total of 10 workers were sampled using the simple random sampling technique even though the companies were not of the same size. Thus, a total of 1550 employees of private companies in the western region were sampled. Workers were interviewed using structured questionnaires to collect primary data. The structured questionnaire was employed in a more interactive manner. This approach provided an in-depth understanding of relevant issues which are very crucial for a good research. It also facilitated an assessment of the knowledge level of managers and employees of private sector firms about HIV/AIDS issues such as: Meaning of HIV, Meaning of AIDS, Mode of Transmission, Anti Retroviral Drug and its use and the effect of HIV/AIDS on private companies.

\section{RESULTS}

\section{Knowledge Levels about HIV}

The knowledge level of HIV/AIDS in the Private Sector with regards to the meaning of $\mathrm{Hu}$ - man Immune Virus (HIV) was quite high. Interview conducted with managers of private firms with existing workplace policies revealed that four out of five $(80 \%)$ knew the meaning of HIV. Regarding managers of companies without the policy, Table 2 indicates that 75 managers $(50 \%)$ knew what HIV meant while 43 managers $(27.5 \%)$ were of the view that HIV and AIDS were the same showing clearly that they did not know that there is a distinction between the two. The remaining 33 representing $22.5 \%$ lacked any form of knowledge about the HIV. Some of these persons were of the view that HIV was just another virus.

HIV Knowledge levels among employees of companies' with HIV/AIDS workplace policies were higher than their counterparts employed by companies without a policy. While about 35 (70\%) employees of companies with HIV/ AIDS workplace policies knew exactly what HIV meant, 525 (35\%) employees in companies without the policies had such knowledge. The percentage of workers with no knowledge about HIV was higher (i.e. 56\%) in companies without workplace policies than those with policies as can be seen in Table 2. This high knowledge level of employees of companies with policies could be attributed to the existence and implementation of the HIV/AIDS Workplace policies.

\section{Knowledge Levels about AIDS}

With regards to the meaning of AIDS among managers of firms without HIV/AIDS workplace policies, $98(65 \%)$ knew what AIDS meant, while 19 (13\%) of the respondents lacked knowledge of what AIDS was (See Table 3$)$. The remaining 33 (22\%) of private sector firms without a workplace HIV/AIDS policy did not appreciate that HIV and AIDS had a link as is depicted in Table 3. On the other hand, all the managers of the five private firms with existing workplace policies knew exactly what AIDS meant through the annual advocacy and educational programmes outlined in their policies. 
Table 2: Knowledge levels about HIV

\begin{tabular}{|c|c|c|c|c|c|c|c|c|}
\hline \multirow{2}{*}{$\begin{array}{l}\text { Knowledge Lev- } \\
\text { els about HIV }\end{array}$} & \multicolumn{2}{|c|}{$\begin{array}{l}\text { Managers of } \\
\text { Companies } \\
\text { without the } \\
\text { Policy }\end{array}$} & \multicolumn{2}{|c|}{$\begin{array}{l}\text { Managers of } \\
\text { Companies } \\
\text { with the Policy }\end{array}$} & \multicolumn{2}{|c|}{$\begin{array}{l}\text { Employees of } \\
\text { Companies with- } \\
\text { out the Policy }\end{array}$} & \multicolumn{2}{|c|}{$\begin{array}{l}\text { Employees of } \\
\text { Companies with } \\
\text { the Policy }\end{array}$} \\
\hline & No. & $\%$ & No. & $\%$ & No. & $\%$ & No. & $\%$ \\
\hline Lack knowledge & 33 & 22.5 & - & - & 840 & 56.0 & 6 & 12.0 \\
\hline Partial knowledge & 42 & 27.5 & 1 & 20.0 & 135 & 9.0 & 9 & 18.0 \\
\hline Full knowledge & 75 & 50.0 & 4 & 80.0 & 525 & 35.0 & 35 & 70.0 \\
\hline Total & 150 & 100 & 5 & 100.0 & 1500 & 100.0 & 50 & 100.0 \\
\hline
\end{tabular}

A similar situation as pertained with HIV knowledge levels among employees was observed with regards to AIDS knowledge levels. From Table 3, around 40 (80\%) of employees in companies with the policy had full knowledge which means that they know that the disease is caused by HIV and that no cure has yet been found, while 540 employees (36\%) of their colleagues in companies without the policy had full knowledge. The remaining ten (20\%) employees of companies with HIV/ AIDS workplace policies had partial knowledge and were of the opinion that AIDS was a killer disease with no cure but did not know that it was caused by the Human Immune Virus (HIV). The percentage of employees in companies without a policy with such partial knowledge was $48 \%$ representing 720 employees; hence they miss the link it has with HIV while $16 \%$ did not know anything about the disease as shown in Table 3.
Knowledge Levels about Mode of Spreading/ Transmission

Majority of managers from both private companies with the policy and those without the policy (about 124 representing 80\%) acknowledged that the sharing of sharp and piercing objects, blood transfusion and unprotected sex were the most common modes of transmission. These are the traditionally known modes of transmissions. Transmission from mother-tochild was not known until recently so it was therefore not surprising that only $28(18 \%)$ sampled managers knew that the HIV virus could be transmitted in such a way. When the knowledge level of managers and owners of firms without the policy with respect to the modes of transmission of the HIV/AIDS pandemic was analyzed, various interesting findings were made. About $12(8 \%)$ managers and owners of private sector firms without the policy mentioned kissing of infected persons and

Table 3: Knowledge levels about AIDS

\begin{tabular}{|c|c|c|c|c|c|c|c|c|}
\hline \multirow{2}{*}{$\begin{array}{l}\text { Knowledge } \\
\text { Levels about } \\
\text { AIDS }\end{array}$} & \multicolumn{2}{|c|}{$\begin{array}{l}\text { Managers of } \\
\text { Companies with- } \\
\text { out the Policy }\end{array}$} & \multicolumn{2}{|c|}{$\begin{array}{l}\text { Managers of } \\
\text { Companies } \\
\text { with the Policy }\end{array}$} & \multicolumn{2}{|c|}{$\begin{array}{l}\text { Employees of } \\
\text { Companies with- } \\
\text { out the Policy }\end{array}$} & \multicolumn{2}{|c|}{$\begin{array}{l}\text { Employees of } \\
\text { Companies with } \\
\text { the Policy }\end{array}$} \\
\hline & Absolute & $\%$ & Absolute & $\%$ & Absolute & $\%$ & Absolute & $\%$ \\
\hline Lack knowledge & 19 & 13.0 & - & - & 240 & 16.0 & (2) & - \\
\hline $\begin{array}{l}\text { Partial } \\
\text { knowledge }\end{array}$ & 33 & 22.0 & - & - & 720 & 48.0 & 10 & 20.0 \\
\hline Full knowledge & 98 & 65.0 & 5 & 100 & 540 & 36.0 & 40 & 80.0 \\
\hline Total & 150 & 100.0 & 5 & 100.0 & 1500 & 100.0 & 50 & 100.0 \\
\hline
\end{tabular}


witchcraft as some of the modes of transmission.

From the employee survey, about $68 \%$ of the entire worker population that was sampled had the knowledge that the disease could be acquired through three main transmission modes, namely unprotected sex, blood transfusion from an infected patient and the sharing of sharp objects such as needles and razor blades with infected persons. The percentage differentials is clearly seen when the worker population is disaggregated based on the existence of a workplace policy on the pandemic. About $40(80 \%)$ employees who had the above stated level of knowledge about the various modes of transmission of the disease were working in companies that were implementing HIV/AIDS workplace policies. On the same issue, two hundred and ten employees (14\%) in companies without the policy had such knowledge. Here the positive effects that the existence of a workplace HIV/AIDS policy brings are evident as there is high level of knowledge in companies with the policy than in those without the policy.

\section{Knowledge Levels about Anti Retroviral Drugs and Use}

Managers of all five private companies with HIV/AIDS workplace policies were well informed about anti- retroviral drugs and their use. Only $30 \%$ of managers of private companies without workplace HIV/AIDS policies had knowledge that anti- retrovirals were drugs that could help secure the immune system of victims and that it is not meant to cure the disease. While $48 \%$ were of the opinion that the drugs could cure the disease, $20 \%$ replied that they have not even heard of it before as depicted in Table 4. The existence of Anti-retroviral drugs for infected persons was known by about $27 \%$ of workers in companies without the policy whiles all employees of companies with the policy were knowledgeable in this area.

This means that managers and employees of companies with the policy would be more receptive to victims than their counterparts without the policy, because at least they are aware of the existence of treatment. To a large extent, this phenomenon can be readily attributed to the existence of the policy as well as the massive educational programmes undertaken through both the print and electronic media (television and radio). Other sources of information that were outlined by employees included community outreach programmes which are organized by AIDS campaigners such as the Private Enterprise Foundation and other NonGovernmental Organizations (NGOs) and Community Based Organizations (CBOs) and from friends and relatives.

\section{Effects of HIV/AIDS on Business}

The survey revealed that $152(97.5 \%)$ managers of all companies surveyed agree that HIV/ AIDS has a negative impact on the operations of businesses. This indicates that awareness levels about the dangers of HIV/AIDS on business operations are very high. A reduction in the labour force due basically to deaths from the disease and the difficulty in finding suitable replacements to be trained to replace such staff were some of the impacts mentioned. Also the

Table 4: Knowledge levels about Anti-Retroviral Drugs and use

\begin{tabular}{|c|c|c|c|c|c|c|c|c|}
\hline \multirow{2}{*}{$\begin{array}{l}\text { Knowledge Lev- } \\
\text { els about Anti } \\
\text { Retroviral Drugs } \\
\text { and Its Use }\end{array}$} & \multicolumn{2}{|c|}{$\begin{array}{l}\text { Managers of } \\
\text { Companies with- } \\
\text { out the Policy }\end{array}$} & \multicolumn{2}{|c|}{$\begin{array}{l}\text { Managers of } \\
\text { Companies } \\
\text { with the Policy }\end{array}$} & \multicolumn{2}{|c|}{$\begin{array}{l}\text { Employees of } \\
\text { Companies with- } \\
\text { out the Policy }\end{array}$} & \multicolumn{2}{|c|}{$\begin{array}{l}\text { Employees of } \\
\text { Companies } \\
\text { with the Policy }\end{array}$} \\
\hline & No. & $\%$ & No. & $\%$ & No. & $\%$ & No. & $\%$ \\
\hline Lack knowledge & 33 & 22.0 & - & - & 840 & 56.0 & - & - \\
\hline Partial knowledge & 72 & 48.0 & - & - & 255 & 17.0 & 5 & 11 \\
\hline Full knowledge & 45 & 30.0 & 5 & 100 & 405 & 27.0 & 45 & 89 \\
\hline Total & 150 & 100.0 & 5 & 100 & 1500 & 100.0 & 50 & 100 \\
\hline
\end{tabular}




\section{Decardi-Nelson and Nsiah-Peprah}

issue of stigmatisation of workers was of major concern to these private companies as it resulted in people not being honest about their status.

\section{Existence of Health Policy}

About 132 companies including those with and without the policy (representing $85 \%$ of all sampled companies) run health budgets. Some companies even have their own clinics or have arrangements with some private and public clinics where their workers and their immediate families go for treatment. Ironically none of the sampled companies had a specific percentage of its expenditure earmarked to be spent on HIV/AIDS. None of them had a special budget for HIV/AIDS activities. This is an indication of how difficult it is to get companies to willingly budget for HIV/AIDS education and also the fact that because the disease takes a long time to manifest, businesses do not fully see its effects.

The main reason given for the non-existence of any form of health policy was that the companies were young and also most of the workers were temporal. Out of the $18(15 \%)$ who did not have any form of health budget within the company, nine $(50 \%)$ intended to run a health budget in the near future. The remaining nine $(50 \%)$ did not have any intentions of instituting workplace health policies and budgets.

\section{Companies' Readiness to Support HIV/ AIDS Workplace Policies}

Table 5 shows that, $85 \%$ of the companies without HIV/AIDS workplace policies expressed their readiness to support HIV/AIDS workplace policies. About $10 \%$ were not willing to support any such programmes basically because they thought it is the government's responsibility while others fear the financial implications. The remaining 5\% could not decide whether the management would support any such policy. Incidentally all the companies whose managers could not decide were the Partnership and Public Liability Companies. Interestingly, all companies who appreciated the negative impact that HIV/AIDS has on the economy and businesses in particular, were willing and ready to support HIV/AIDS workplace policies and programmes.

Table 5: Companies' readiness to support HIV/AIDS workplace programme

\begin{tabular}{lll}
\hline Responses & Frequency & Percentage \\
\hline Ready & 128 & 85.0 \\
Not Ready & 15 & 10.0 \\
Don't know & 7 & 5.0 \\
Total & $\mathbf{1 5 0}$ & $\mathbf{1 0 0 . 0}$ \\
\hline
\end{tabular}

Majority of companies (77 representing 60\%) who were willing and ready to support HIV/ AIDS workplace policies, were ready to increase budgetary support for such programmes including treatment of opportunistic infections and making Anti Retrovial drugs available to victims in their companies. More often than not companies are willing to pay for treatment of diseases such as diarrhoea, recurring fever and to some extent tuberculosis without knowing that these diseases could be or are some form of opportunistic infections that one gets as one acquires HIV/AIDS. Also high on the list of interventions was an increase in efforts at promoting the use of condoms by workers and people in the immediate communities. About half of the private companies who were willing and ready to support HIV/AIDS workplace policies, confirmed their readiness to collaborate with existing systems such as the Private Enterprise Foundation (PEF), Netherlands Embassy Programme and the Treatments Acceleration Programme (TAP) to provide comprehensive HIV/AIDS services and also organize periodic sensitization meetings, durbars, and drama shows at workplaces on HIV/AIDS.

\section{DISCUSSIONS}

With the high knowledge level about HIV/ AIDS among managers of the sampled private companies, their appreciation of the enormity of the impact of the pandemic is good. This notwithstanding, no locally owned Ghanaian private company has an HIV/AIDS workplace 
policy. The companies surveyed cited financial constraints as their major reason for not having any workplace policy or even programme on HIV/AIDS.

There is no legal backing for the HIV/AIDS Workplace Policy which means that only dialogue can be used to get most companies, if not all to formulate and implement HIV/AIDS workplace policies. No institution in the country, not even the Ghana AIDS Commission has the statistics of the number of private companies in the country who have formulated and are working with the policy. The policy needs to be given a legal status so that it becomes binding on all companies whether private or public to formulate and implement one. The seriousness that needs to be attached to this stems from the devastating impacts that this pandemic is having on the nation's human resources even though it is quite difficult to quantify the impacts.

The only companies which are working with the HIV/AIDS policy are the mining firms, which incidentally are multinational companies. This is because to these companies the existence of a workplace HIV/AIDS policy shows the extent of their social responsiveness, something that gives them a good public image. Again due to the huge financial outlay of the mining companies, they have enough resources at their disposal to embark upon educational programmes for both their workers and the immediate surrounding communities. It is clear that the 150 companies without the workplace HIV/AIDS policy see themselves as not being financially placed to undertake such an investment to which there are no immediate profits. All 150 sampled companies without the policy do not have the financial strength of the five mining companies.

With the increase in the number of mining companies in the western region, one can expect an increase in the immigrant population and its influence on attitudes and behaviours. These socio-economic changes have been found to have direct links with the risk and spread of HIV/AIDS (Amoa, 2004). This may create or aggravate circumstances that make the workforce and the entire population vulnerable to HIV/AIDS.

Managers of sampled private companies were aware of the negative impact of the disease on the workforce and therefore would be willing to help mitigate this impact. This is a very good sign of how prepared private firms were to ensure that the prevalence rate of the disease is further reduced and also to mitigate the impact it is having on businesses. It is also good because it means that these companies would open their doors to any form of intervention geared towards helping them to formulate and implement workplace HIV/AIDS Policies and programmes. The problem left to be solved is how to translate their willingness into commitment to provide adequate funds for the purpose of fighting HIV at the workplace into reality.

Knowledge levels of both the managers and employees of the five private companies with the policy were very high because of the implementation of the programmes outlined in these policies most of which were drawn in line with the ideal National HIV/AIDS Workplace policy. Also, knowledge levels within companies without the policy was encouraging obviously justifying the huge amounts that have been spent on educational programmes by the Ghana AIDS Commission and other development partners over the years. Again it shows that the foundation has been laid and that all the private sector needs to do is to institute annual programmes to ensure that this knowledge translates into changes in behaviour. However, this foundation that has been laid by the Commission needs to be built upon and at a fast pace.

This can easily be achieved if companies have dedicated periods for HIV/AIDS education which would transcend community boundaries and impact on all persons within the immediate surroundings. 


\section{Decardi-Nelson and Nsiah-Peprah}

\section{CONCLUSION}

This paper has attempted to establish a correlation between the implementation of HIV/AIDS Workplace Policies and knowledge levels of managers and employees about the pandemic. This has been shown from the analysis of the data gathered. Thankfully, there is a National HIV/AIDS Workplace Policy that is to serve as a guide for all companies to follow but it needs legal backing for enforcement. It is hoped that by the end of 2010 when the policy is expected to be reviewed based on the 2006-2010 timeframe, a lot more companies if not all, would have initiated comprehensive HIV/AIDS policies at their various workplaces. This would give the employees and their immediate families and in the broader sense the surrounding communities, knowledge about what to do to protect themselves from being victims of the disease and hence help reduce its prevalence rate and mitigate the negative socio-economic and developmental impact.

\section{RECOMMENDATIONS}

It is significant to note that more companies are beginning to appreciate the effects of HIV/ AIDS on their operations. However, what is lacking is their ability to initiate workplace programmes to combat HIV/AIDS at the workplace on a sustainable basis. There is the need to intensify educational programmes by the Ghana AIDS Commission that would provide in-depth information on mode of transmission and prevention of HIV/AIDS. In the short term, the following recommendations are made:

- Managements of the private companies need support and encouragement to implement these policies. It is therefore recommended that institutions such as the Private Enterprise Foundation (PEF) and the Family Life International under the Treatment Acceleration Project organise advocacy programmes for such companies to work with HIV/AIDS workplace policies. Also, private firms' umbrella institutions and bodies in Ghana such as the PEF, Association of Ghana Industries (AGI), Association of Small Scale Industries (ASSI) and
National Board for Small Scale Industries (NBSSI) should champion the formulation of HIV/AIDS workplace policies in their member companies. This would be a bold step towards increasing the knowledge levels which are a prerequisite for mitigating the impact of the pandemic.

- Due to the expensive nature of the Antiretroviral drugs, corporate bodies need to partner with government in supplying these drugs to victims. This public-private partnership in making these drugs available and affordable to the victims needs to be promoted by the Ghana AIDS Commission. Hence, the private companies should be encouraged by the government to include payment for such drugs in their health budgets.

In the long run, there is an urgent need for the HIV/AIDS workplace policy to be given legal backing by the government so that it will be incumbent on all companies be they public or private to have an HIV/AIDS workplace policy. Companies who fail to comply should be sanctioned. Therefore the Ghana AIDS Commission together with all stakeholders have to put in motion an advocacy plan of lobbying for this legal backing.

\section{REFERENCES}

Amoa, S. A. (2004). HIV/AIDS and Policy Response Challenges; A Paper Presented at the $4^{\text {th }}$ CHAG Interactive Workshop on the World of Work and HIV/AIDS $18^{\text {th }}$ $19^{\text {th }}$ November, 2004, Accra, Ghana.

Decosas, J. (1996). The Effect of HIV on Health Care in Sub-Saharan Africa. Development Southern Africa. 13(1). 34-39.

Decosas, J. and Adrien, A. (1997). Migration and HIV/AIDS, (Supplement A): pp. 7784.

Ghana AIDS Commission (2005a). National HIV/AIDS Strategic Framework II 20062010, Accra, Ghana. 
Workplace HIVIAIDS Policy and impact on Knowledge levels... 54

Ghana AIDS Commission (2005b). National Integrated IEC/BCC Strategic Framework (HIV and AIDS), 2006-2010, Accra, Ghana.

Ghana AIDS Commission (2005c). National Workplace HIV/AIDS Policy, Accra, Ghana.

Government of Ghana (GoG) (2005). Growth and Poverty Reduction Strategy (GPRSII) (2006-2009) Accra, Ghana.
International Labour Organization (2000). HIV/ AIDS and Labour: A Situational Analysis on Ghana, Accra, Ghana.

WHO (2007). 'Towards Universal Access: Scaling up priority HIV/AIDS interventions in the Health sector. New York.

Yeboah-Duah, K. (2002). Developing an HIV/ AIDS Prevention Programme. Private Enterprise Foundation, Accra, Ghana. 